\begin{tabular}{lccc} 
& GOSPODARKA & SUROWCAMI & MINERALNYMI \\
\hline Tom 29 & 2013 & Zeszyt 2 \\
& DOI 10.2478/gospo-2013-0017 &
\end{tabular}

\author{
MICHAL GUZIUREK*, VOJTECH ZECHNER*, PETER FECKO**
}

\title{
Application of brown coal pyrolytic oils in black coal slurry flotation
}

\section{Introduction}

Flotation plays an irreplaceable role in separation processes. It is used in the retrieval of useful components from metallic ores and the recovery of coal from tailings ponds or fine grained waste produced during mining. Flotation can generate high-quality coal with low ash content. However, this process is usually more expensive than jigging or sink-float separation. Nevertheless, the application of alternative flotation agents may lead to less costly flotation processes. In particular, pyrolysis of brown coal appears to offer a suitable method of obtaining alternative flotation agents. The liquid pyrolytic product could be employed in flotation, while other (both gas and solid) pyrolytic products may be used in various technologies or processes such as alternative fuels, sorbents, etc.

Liquid pyrolytic products have specific properties depending on the feedstock as well as the pyrolytic process conditions. Because one of the characteristics is the capacity of selectivity in coal flotation, there is an option to use pyrolytic oils as flotation agents. Already, Perez and Cortez (1996) used pyrolytic oils in the flotation of copper ores (Brossard, Cortez 1997). Others who took advantage of pyrolysis oil for flotation (coal) were Fečko et al. (2010).

Brown coal unsuitable for energy recovery purposes due to its high sulphur content would be used to make alternative agents, or the agents could be obtained as by-products of

* Eng. ** Professor, CSc., VŠB - Technical University of Ostrava, Faculty of Mining and Geology, Institute of Clean Technologies for Extraction and Utilization of Energy Resources, Ostrava-Poruba, Czech Republic; e-mail: michal.guziurek@gmail.com 
brown coal pyrolysis, the major products being char or gas for different purposes (Kasztelewicz 2004; Lorenz, Grudziński 2005).

Pyrolysis is a thermal process during which sulphide and sulphur oxides are formed, and its negative impacts on the environment are known. Desulphurization during pyrolysis using Ca-additives is not applicable as the additives reduce the liquid product yields as confirmed, for example, by Ahmad et al. (2009).

Bacterial sulphur removal resulting in reduced sulphur content in coal appears to be a suitable method. During its pyrolysis, lower or minimal amounts of sulphur compounds arise which pass into the liquid and gas products. Finally, the liquid products are used in flotation as alternative flotation agents.

The goals of this analysis are as follows:

— biodesulphurization of high-sulphur brown coal applying Bacterium Acidithiobacillus ferrooxidans

— pyrolysis of desulphurized and non-desulphurized brown coal to gain liquid products,

- application of the liquid pyrolytic products in black coal slurry flotation, both separately and mixed with a conventional flotation agent of Montanol 800,

- obtaining flotation concentrates with ash content below $10 \%$,

- comparing the alternative flotation agents with the conventional flotation agent Montanol 800,

- determining whether sulphur in coal influences the final function of the produced pyrolytic oil applied as a flotation agent.

\section{Methods}

The brown coal samples were extracted from a locality called Eliška in the Most Region (according to ČSN ISO 441313 Standard). The sampling point was located by the side of the road above hole HJI329, roughly $1 \mathrm{~m}$ above the foot of seam. The seam is described as xylitic-detritic coal, except for the initial section, followed by a sharp transition into the seat comprised of silty, light-grey claystone with $\mathrm{FeS}_{2}$ aggregates.

The brown coal samples were obtained from the company Sokolovská uhelná, the Antonin seam of the Jiri Mine. This coal seam is characterized by the alternation of decimetre-thick bright and dull positions corresponding to the alternation of liptodetrites and liptobiolites with darker humites. In the upper parts of the seam, xylitic components prevail, while detritic components dominate toward the lower section of the seam. The coal was drawn from the third coal cut above the parting labelled 30. This coal is rich in sulphur and contains pyrite.

The collected samples were first crushed in a jaw crusher. Next, a smaller mill was used to further crush the coal, and the required particle size was obtained by means of a control sieve shaker below $0.5 \mathrm{~mm}$ for bacterial leaching, and a fraction below $3 \mathrm{~mm}$ which was pyrolyzed at the Institute of Rock Structure and Mechanics of the Academy of 
Sciences of the CR in Prague (ÚSMH AVČR) as a non-desulphurized brown coal sample from the Jiří Mine.

Despite existing documentation (Fečko 2008; Ghauri et al. 2009) implying that bacterial leaching is more efficient with a grain size from 70 to about 150 ěm, the coal samples were ground $100 \%$ below $0.5 \mathrm{~mm}$ to comply with the technological requirements of pyrolysis. The feed of the individual samples was $500 \mathrm{~g}$, and was placed into ten-litre reactors. After pouring in 7 litres of $9 \mathrm{~K}$ medium free of $\mathrm{FeSO}_{4}$ and homogenization of the suspension, $1100 \mathrm{ml}$ of pre-cultured bacterial culture of Acidithiobacillus ferrooxidans was added in a concentration of $10^{9}$ bacteria per $1 \mathrm{ml}$ of bacterial solution. Stirring and aeration of the suspension were ensured by an aeration apparatus connected to the reactor. The leaching process lasted for 28 days at laboratory temperature. The $\mathrm{pH}$ value in the suspension was measured by a laboratory $\mathrm{pH}$ metre, and during the overall experiment $\mathrm{pH}$ was kept at an optimal value ranging from 1.8 to 2.2 applying $\mathrm{H}_{2} \mathrm{SO}_{4}(5 \mathrm{~mol} / \mathrm{l})$. After leaching, the samples were washed in distilled water, dried, and then underwent a chemical analysis in the Brown Coal Research Institute in Most. Pyrolysis was carried out using part of the desulphurized and non-desulphurized samples at ÚSMH AVČR.

At ÚSMH AVČR, a laboratory pyrolytic was used. The device can hold a maximum feed of $400 \mathrm{~g}$ and the top temperature is $1000^{\circ} \mathrm{C}$. The heating process is controlled by a microprocessor and the obtained data are recorded by a computer. The device features a vertical ceramic tube of $500 \mathrm{~mm}$ in length and $85 \mathrm{~mm}$ in diameter, around which a kanthal wire is wound ( $\varphi=1.5 \mathrm{~mm}$ ), constituting the core of the unit (output $2.6 \mathrm{~kW}$ ). The tube is placed in a steel shell closed off by a metal bottom and top, and has a ceramic lining. Diatomeous powder functions as thermal and electrical insulation. The reactor is made up by a quartz tube with a sealed bottom, with a diameter of $60 \mathrm{~mm}$ and a length of $500 \mathrm{~mm}$. Volatile products are conducted away from the reactor into a separation section, the condensed liquid products are collected in a flask below the cooler, and the cooled pyrolytic gas is trapped in a gas holder. Cooling is ensured by an outside condensing cooling unit and the temperature of the cooling medium (ethanol) is $-10^{\circ} \mathrm{C}$ (Kříž 2005; Kř́iž, Brožová 2007).

The sample feed for pyrolysis was $100 \mathrm{~g}$. The grain size (due to the desulphurization technology) was $100 \%$ below $0.5 \mathrm{~mm}$. This grain size was used in all the samples from the locality of Eliška, both desulphurized and non-desulphurized. Due to better handling with the samples, a fraction $(0.5$ to $3 \mathrm{~mm}$ ) of the non-desulphurized sample from the Jiří Mine was used for pyrolysis. The heating rate was $5^{\circ} \mathrm{C} / \mathrm{min}$ to a final temperature of $900^{\circ} \mathrm{C}$, and the holding time was $30 \mathrm{~min}$.

From this coal sample (Jiří), an analysis of the produced gas was carried out and the net and gross heat of combustion was calculated from the individual component contents according to the Standards ČSN 385509 and ČSN 385521.

The analysis of liquid pyrolytic products was executed in the laboratories of VŠB-TU Ostrava using an FT-IR spectrometer Nicolet NEXUS 470. Measuring was implemented using the single reflection ATR germanium crystal technique. The spectra were measured within $4000-675 \mathrm{~cm}^{-1}$ doing 512 scans at a resolution of $8 \mathrm{~cm}^{-1}$. The read spectra were 
modified removing the bands of $\mathrm{CO}_{2}$ (around $2300 \mathrm{~cm}^{-1}$ ), an ATR correction was made in order to obtain transmission spectra, and the basic line was automatically interlaid.

The analysis of the formed gas was carried out on the Jiří Mine sample at ÚSMH AVČR using a gas chromatograph Agilent $6890 \mathrm{~N}$ with a flame-ionization detector of hydrogen content and a thermal conductivity detector of hydrogen, carbon oxides, and nitrogen. The determination of sulphur compounds and sulphane in the pyrolytic gas was carried out in a GS-Gaspro column which permits a determination of sulphane content in gas using thermal conductivity detection.

Flotation tests were implemented in the laboratory of the Institute of Environmental Engineering of VSB-TU Ostrava using a laboratory agitation flotation machine. In order to test the efficiency of the flotation oils, pyrolytic oils were obtained by pyrolyzing brown coal from the Most Region (samples Eliška 1 and 2 - desulphurized and non-desulphurized) and from the Sokolov Region (sample Jiří - desulphurized and non-desulphurized). To identify the capacity of the pyrolytic oils to act as flotation agents, the obtained flotation test values were compared with flotation test values from the conventional flotation agent Montanol 800 .

Black coal slurry from the Lazy Mine, OKD a.s., and a settler from the Darkov Mine were used for the flotation tests. Flotation was conducted using the conventional flotation agent of Montanol 800, and then the flotation agents were mixed in various proportions, from 1:4 to 5:0 (pyrolytic oil : Montanol 800). The individual concentrates obtained were evaluated both for ash content as well as for mass yields of the concentrates.

Flotation conditions:

— pulp density - $150 \mathrm{~g} / \mathrm{l}$,

- collector dose $-500 \mathrm{~g} / \mathrm{Mg}$,

- flotation time $-5 \mathrm{~min}$,

- conditioning - 1 (5) $\mathrm{min}$.

During the experiments it was concluded that the flotation results using the coal slurry from the Darkov Mine did not meet the target (ash content in the concentrate below 10\%), the conditioning time was prolonged from 1 to 5 minutes, and the overall process with all the agents was repeated.

\section{Results and discusion}

The elementary analyses of the coal samples identified the contents of the observed elements as dry and ash free, and by water content, ash content, and net and gross heat of combustion.

It is clear from Table 1 that the coal samples from Eliška have a very similar composition, and the differences are in the order of tenths of percents. Next, the values imply that the Jiři coal sample contains about 4\% less carbon than the Eliška samples, while the oxygen content is higher. The sulphur content in the Jiř́ sample is almost double that of the Eliška samples. 
The elementary analyses of the coal samples [\%]

Analizy elementarne próbek węgla [\%]

\begin{tabular}{|l|c|c|c|c|c|c|c|c|c|c|}
\hline \hline \multicolumn{1}{|c|}{ Sample } & $\mathrm{C}^{\mathrm{d}}$ & $\mathrm{H}^{\mathrm{d}}$ & $\mathrm{N}^{\mathrm{d}}$ & $\mathrm{O}^{\mathrm{d}}$ & $\mathrm{S}^{\mathrm{d}}$ & $\mathrm{C}^{\text {daf }}$ & $\mathrm{H}^{\text {daf }}$ & $\mathrm{N}^{\text {daf }}$ & $\mathrm{O}^{\text {daf }}$ & $\mathrm{S}^{\text {daf }}$ \\
\hline \hline Eliška 1 & 65.00 & 6.10 & 0.80 & 16.61 & 1.77 & 71.99 & 6.76 & 0.89 & 18.40 & 1.96 \\
\hline Eliška 2 & 65.10 & 6.25 & 0.79 & 16.06 & 1.71 & 72.41 & 6.95 & 0.88 & 17.86 & 1.90 \\
\hline Jiří & 61.91 & 6.13 & 0.82 & 19.02 & 3.58 & 68.65 & 6.81 & 0.91 & 21.11 & 3.96 \\
\hline \hline
\end{tabular}

$\mathrm{X}^{\mathrm{d}}$ - element content as dry; $\mathrm{X}^{\mathrm{daf}}$ - element content as dry and ash free; $\mathrm{C}$ - carbon content; $\mathrm{H}$ - hydrogen content; $\mathrm{N}$ - nitrogen content; $\mathrm{O}$ - oxygen content; $\mathrm{S}$ - sulphur content.

TABLE 2

The elementary analyses of the coal samples, forms of sulphur

TABELA 2

Analizy elementarne próbek węgla i form siarki

\begin{tabular}{|l|c|c|c|c|c|c|c|c|}
\hline \multicolumn{1}{|c|}{ Sample } & $\begin{array}{c}\mathrm{W}^{\mathrm{a}} \\
{[\%]}\end{array}$ & $\begin{array}{c}\mathrm{A}^{\mathrm{d}} \\
{[\%]}\end{array}$ & $\begin{array}{c}\mathrm{daf}^{\mathrm{d}} \\
{[\%]}\end{array}$ & $\begin{array}{c}\mathrm{Q}_{\mathrm{s}}{ }^{\mathrm{d}} \\
{[\mathrm{MJ} / \mathrm{kg}]}\end{array}$ & $\begin{array}{c}\mathrm{Q}_{\mathrm{i}}{ }^{\mathrm{d}} \\
{[\mathrm{MJ} / \mathrm{kg}]}\end{array}$ & $\begin{array}{c}\mathrm{S}_{\mathrm{s}} \\
{[\%]}\end{array}$ & $\begin{array}{c}\mathrm{S}_{\mathrm{p}} \\
{[\%]}\end{array}$ & $\begin{array}{c}\mathrm{S}_{\mathrm{o}} \\
{[\%]}\end{array}$ \\
\hline \hline Eliška 1 & 11.05 & 9.72 & 90.28 & 28.32 & 26.99 & 0.45 & 0.21 & 1.11 \\
\hline Eliška 2 & 8.75 & 10.10 & 89.90 & 28.53 & 27.17 & 0.44 & 0.21 & 1.06 \\
\hline Jiř́í & 14.40 & 18.32 & 81.68 & 27.23 & 25.71 & 1.20 & 2.10 & 0.28 \\
\hline
\end{tabular}

$\mathrm{W}^{\mathrm{a}}$ - water content; $\mathrm{A}^{\mathrm{d}}$ - ash content as dry; daf $\mathrm{f}^{\mathrm{d}}$ - content of dry pure coal substance; $\mathrm{Q}_{\mathrm{s}}{ }^{\mathrm{d}}-$ gross heat of combustion; $\mathrm{Q}_{\mathrm{i}}{ }^{\mathrm{d}}$ - net heat of combustion; $\mathrm{S}_{\mathrm{s}}-$ sulphate sulphur; $\mathrm{S}_{\mathrm{o}}$ - organic sulphur; $\mathrm{S}_{\mathrm{p}}-$ pyritic sulphur.

It is apparent from the values in Table 2 that the Jiří sample, in contrast to the Eliška sample, is from low-grade coal as it contains twice as much ash, i.e. $18.32 \%$, and the content of pure coal substance is lower by 8 or $9 \%$. The net and gross heat of combustion is around 26.6 or $28 \mathrm{MJ} / \mathrm{kg}$. Further, it is clear that the Jiří Mine coal contains $2.1 \%$ of pyritic sulphur and $0.28 \%$ of organic sulphur, while the sulphur values are opposite in the Eliška sample. This implies that the Jiří sample comprises more pyrite and less organic sulphur compounds than the Eliška sample.

Given the oxygen content in the brown coal samples, the formation of organic compounds with oxygen groups can be expected during pyrolysis, e.g. alcohols or phenols, the abundance of which was confirmed by the FTIR analysis of the pyrolytic oils.

Bacterial leaching of the coal samples using Acidithiobacillus ferrooxidans in order to reduce sulphur content lasted for 28 days. The results are shown in Table 3.

As Table 3 indicates, the coal drawn from Eliška contained total sulphur content of about $1.7 \%$. The application of bacterial leaching succeeded in the removal of about $30 \%$ of total sulphur. The best results occurred in the case where $97.78 \%$ of sulphate sulphur 
Results of bacterial leaching of samples of brown coal

Wyniki próbek bakteryjnego ługowania węgla brunatnego

\begin{tabular}{|c|c|c|c||}
\hline \hline Sulphur & Prior to leaching [\%] & After leaching [\%] & Sulphur removal [\%] \\
\hline \hline \multicolumn{5}{|c|}{ Sample Eliška 1 } \\
\hline $\mathrm{S}_{\mathrm{c}}$ & 1.77 & 1.21 & 31.64 \\
\hline $\mathrm{S}_{\mathrm{s}}$ & 0.45 & 0.01 & 97.78 \\
\hline $\mathrm{S}_{\mathrm{p}}$ & 0.21 & 0.19 & 9.52 \\
\hline $\mathrm{S}_{\mathrm{o}}$ & 1.11 & 1.01 & 9.01 \\
\hline \multicolumn{4}{|c|}{ Sample Eliška 2 } \\
\hline $\mathrm{S}_{\mathrm{c}}$ & 1.71 & 1.20 & 29.82 \\
\hline $\mathrm{S}_{\mathrm{s}}$ & 0.44 & 0.02 & 95.45 \\
\hline $\mathrm{S}_{\mathrm{p}}$ & 0.21 & 0.19 & 9.52 \\
\hline $\mathrm{S}_{\mathrm{o}}$ & 1.06 & 0.99 & 6.60 \\
\hline \multicolumn{5}{|c|}{} & Sample Jiří \\
\hline $\mathrm{S}_{\mathrm{c}}$ & 3.58 & 1.51 & 57.82 \\
\hline $\mathrm{S}_{\mathrm{s}}$ & 1.20 & 0.48 & 60.00 \\
\hline $\mathrm{S}_{\mathrm{p}}$ & 2.10 & 0.85 & 59.52 \\
\hline $\mathrm{S}_{\mathrm{o}}$ & 0.28 & 0.18 & 35.71 \\
\hline \hline
\end{tabular}

$\mathrm{S}_{\mathrm{c}}$ - total sulphur; $\mathrm{S}_{\mathrm{s}}-$ sulphate sulphur; $\mathrm{S}_{\mathrm{p}}$ - pyritic sulphur; $\mathrm{S}_{\mathrm{o}}$ - organic sulphur.

was removed from the Eliška 1 sample, and over 95\% from the Eliška 2 sample. Applying the bacteria on the Jiŕi sample, $57.82 \%$ of total sulphur was removed and its content dropped from the original $3.58 \%$ to $1.51 \%$. The worst result occurred in the organically combined sulphur, i.e. $35 \%$.

Comparing the percentage removal of pyritic sulphur from the samples Eliška and Jiří, there is a clear difference. From the Jiř́i sample, almost six times more pyritic sulphur was removed than from the Eliška sample. In all probability this is due to pyrite in the Eliška sample being more intergrown throughout the coal grain than in the Jiří sample.

As is shown in Table 4, out of $100 \mathrm{~g}$ of non-desulphurized coal sample from the Most Region, the process obtained about $48 \mathrm{~g}$ of solid product (char), slightly over $33 \mathrm{~g}$ of liquid products, and the rest (approximately $19 \mathrm{~g}$ ) became gas products. The weights of the desulphurized coal sample products differed slightly where the char yield rose by $3 \%$ (to almost 51\%) and the weight of the pyrolytic oil decreased to $30 \mathrm{~g}$. Again, about $19 \mathrm{~g}$ of gas products were obtained.

From the Jiří Mine brown coal, almost $50 \mathrm{~g}$ of liquid product were obtained from the non-desulphurized sample and $35.40 \mathrm{~g}$ from the desulphurized sample. The weight of 
Final mass of the pyrolytic products, samples Eliška 1, 2 and Jiři

Końcowa masa pirolitycznychproduktów z próbek węgla Eliska 1, 2 i Jiři

\begin{tabular}{||l|c|c|c|c||}
\hline \multicolumn{1}{|c|}{ Sample } & Navážka $[\mathrm{g}]$ & Koks & Kapalné produkty $[\mathrm{g}]$ & Plyn $[\mathrm{g}]$ \\
\hline \hline Eliška 1 non-desulphurized & 100.00 & 48.10 & 33.50 & 18.40 \\
\hline Eliška 2 non-desulphurized & 100.00 & 47.80 & 33.20 & 19.00 \\
\hline Jiří non-desulphurized & 100.00 & 37.14 & 49.59 & 8.30 \\
\hline Eliška 1 desulphurized & 100.00 & 50.90 & 29.90 & 19.20 \\
\hline Eliška 2 desulphurized & 100.00 & 50.10 & 30.90 & 19.00 \\
\hline Jiří desulphurized & 100.00 & 48.48 & 35.40 & 10.20 \\
\hline \hline
\end{tabular}

the gas products was around $9 \mathrm{~g}$. As the samples were of different grain sizes, it is possible there was an influence on the individual product yields. There is space for discussion there as Hanson et al. (2002) claim that in particles of $0.5-2.8 \mathrm{~mm}$ there are no apparent impacts on the char yields. In other words, the yields are analogous. However, Kristiansen (1996) states that along with a rise in the particle size there is an increase in the char yield. Hanson et al. (2002) explain the variations in the results by different pyrolysis conditions. They further add that along with an increase in the particle size, the volume of the obtained liquid product decreases as it is better liberated from smaller particles (Hanson et al. 2002; Kristiansen 1996). The table implies that the results of both authors vary. According to Hanson et el. (2002), this may be attributed to different conditions of pyrolysis as from the Jiři sample with a grain size below $0.5 \mathrm{~mm}$, where less tar was obtained than from the non-desulphurized sample below $3 \mathrm{~mm}$ in grain size.

The composition of pyrolytic gas was determined as a by-product (Table 5).

The pyrolytic oil analysis results reveal that the most abundant were hydrogen (about $55 \%$ ), methane (c. 13.4\%), and carbon monoxide (11\%) which roughly corresponds to the composition of coking gas (despite the methane content being half). The volume of gas incombustibles (nitrogen and carbon dioxide) was around $10 \%$. The influence of desulphurization on the gas constituent contents was minimal. It shows only in the content of sulphane, which was lower by $12.6 \%$ in the desulphurized sample. This composition was used to calculate gross and net heat of combustion subject to Standards ČSN 385509 and ČSN 385521.

The values of gross heat of combustion ranged from 18.8 to $19.4 \mathrm{MJ} / \mathrm{m}^{3}$, and the net heat of combustion was around $17.3 \mathrm{MJ} / \mathrm{m}^{3}$. In compliance with Standard ČSN 385502 the gas may be classified as medium calorific and may thus be used as alternative fuel.

The outputs of the FTIR analyses of the Eliška pyrolytic oils are shown in Figures 1 and 2.

The spectra in Figures 1 and 2 imply that they are fairly similar. There is a clear presence of saturated aliphatic hydrocarbons, followed by bands of aromatic hydrocarbons, carbonyl 
The composition of pyrolytic gas [vol.\%]

Skład gazu pirolitycznego [vol.\%]

\begin{tabular}{|c|c|c|}
\hline & Sample Jiř́ non-desulphurized & Sample Jiř́ desulphurized \\
\hline \hline $\mathrm{CH}_{4}$ & 13.16 & 13.70 \\
\hline $\mathrm{C}_{2} \mathrm{H}_{4}$ & 1.76 & 1.53 \\
\hline $\mathrm{C}_{2} \mathrm{H}_{6}$ & 1.59 & 1.52 \\
\hline $\mathrm{C}_{3} \mathrm{H}_{6}$ & 1.43 & 1.25 \\
\hline $\mathrm{C}_{3} \mathrm{H}_{8}$ & 1.28 & 1.30 \\
\hline$\Sigma \mathrm{C}_{4}$ & 0.23 & 0.24 \\
\hline $\mathrm{N}_{2, \mathrm{r}}$ & 1.25 & 1.59 \\
\hline $\mathrm{CO}$ & 11.22 & 11.05 \\
\hline $\mathrm{CO}_{2}$ & 9.33 & 8.87 \\
\hline $\mathrm{H}_{2}$ & 54.78 & 55.67 \\
\hline $\mathrm{H}_{2} \mathrm{~S}$ & 2.07 & 1.81 \\
\hline \hline
\end{tabular}

groups, and water. In the aliphatic hydrocarbons, there are dominant linear chains over branched chains (the proportion of band intensity $2955 \mathrm{~cm}^{-1}$ and $2925 \mathrm{~cm}^{-1}$ significantly shifted in favour of asymmetric vibrations of groups $\mathrm{CH}_{2}$ ). In the non-desulphurized Eliška 1 sample there is much more water than in Eliška 2. In the desulphurized Eliška 2 sample there is more water than in Eliška 1.

The outputs of the FTIR analyses of the Jiří pyrolytic oils are shown in Figures 3 and 4.

The Jiř́ sample pyrolytic oil spectra imply that they contain mainly saturated aliphatic hydrocarbons with dominant longer chains (the band $2925 \mathrm{~cm}^{-1}$ of asymmetric valence vibrations of $\mathrm{CH}_{2}$ group was significantly more intense than the band $2960 \mathrm{~cm}^{-1}$ belonging to the asymmetric valence vibration of $\mathrm{CH}_{3}$ group). The samples also contain water, which is manifested by the band around $3400 \mathrm{~cm}^{-1}$ (including the fine structure of finer bands above $3500 \mathrm{~cm}^{-1}$ ).

The samples' spectra demonstrate very probable bands of aromatic hydrocarbons, phenol, and unsaturated or aromatic aldehydes or ketones. Their closer specification is very difficult due to the water bands present in both the spectra. It may be deduced that the sample of non-desulphurized coal contains a higher proportion of water than the desulphurized coal sample.

Comparing all the IR spectra of the produced pyrolytic oils and the spectrum of the flotation agent Montanol 800, there is correlation in the following bands:

- $3400 \mathrm{~cm}^{-1}$ valence vibrations of -OH water group (probably alcoholic),

- $2960 \mathrm{~cm}^{-1}, 2930 \mathrm{~cm}^{-1}, 2870 \mathrm{~cm}^{-1}$ valence vibrations of group $\mathrm{CH}_{3}$ a $\mathrm{CH}_{2}$ in aliphatic hydrocarbons, 


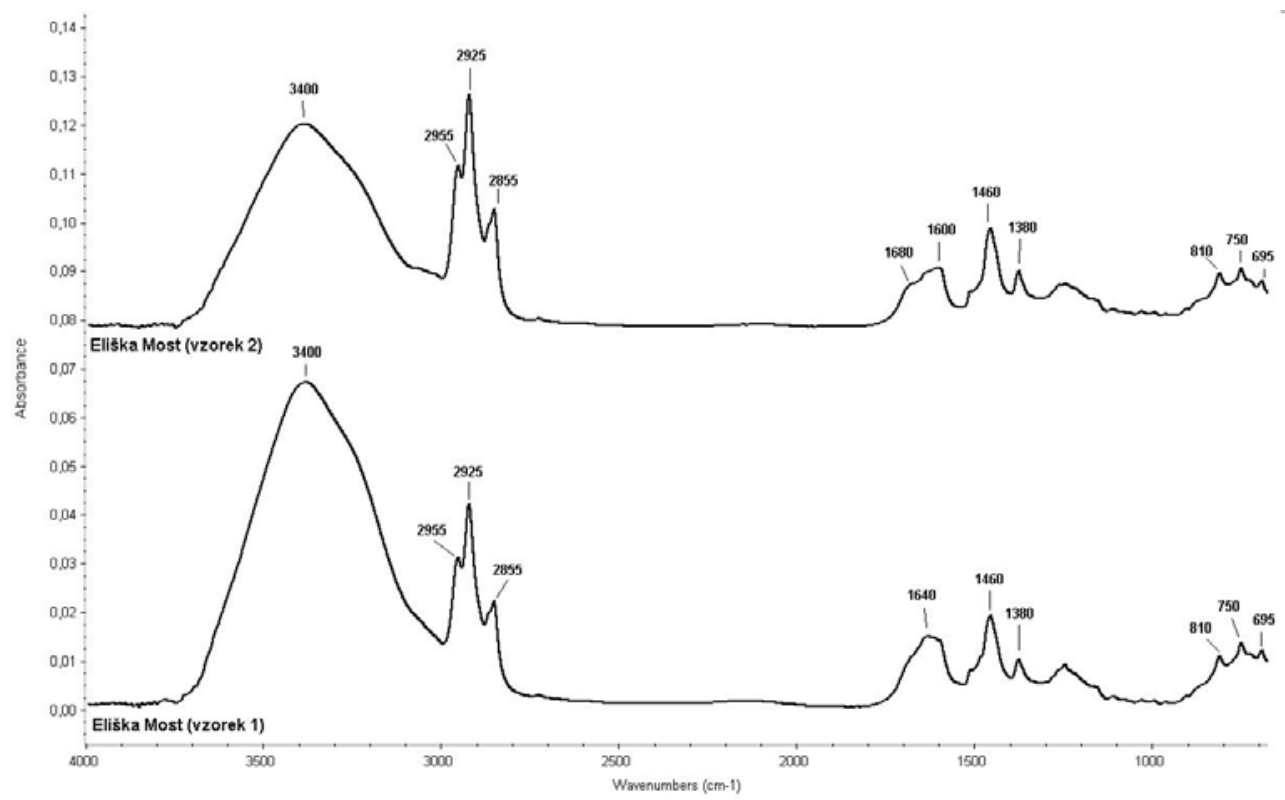

Fig. 1. IR spectrum of the pyrolytic oils - non-desulphurized coal (locality Eliška)

Rys. 1. Widmo IR olejów pirolitycznych - nieodsiarczony węgiel (miejscowość Eliška)

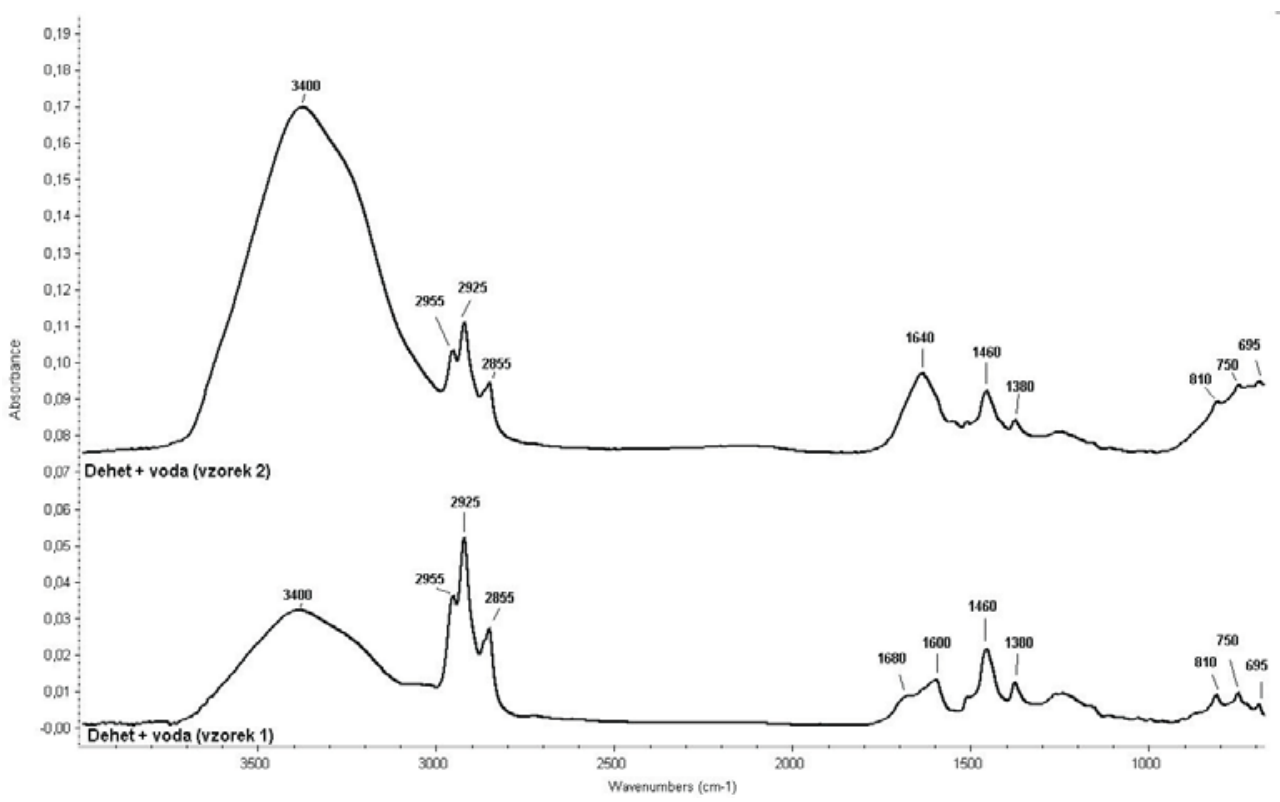

Fig. 2. IR spectrum of the pyrolytic oils -desulphurized coal (locality Eliška)

Tar + water (samples 1 and 2) correspond to the desulphurized samples Eliška 1 and Eliška 2

Rys. 2. Widmo IR olejów pirolitycznych - węgiel odsiarczony (miejscowość Eliška) 


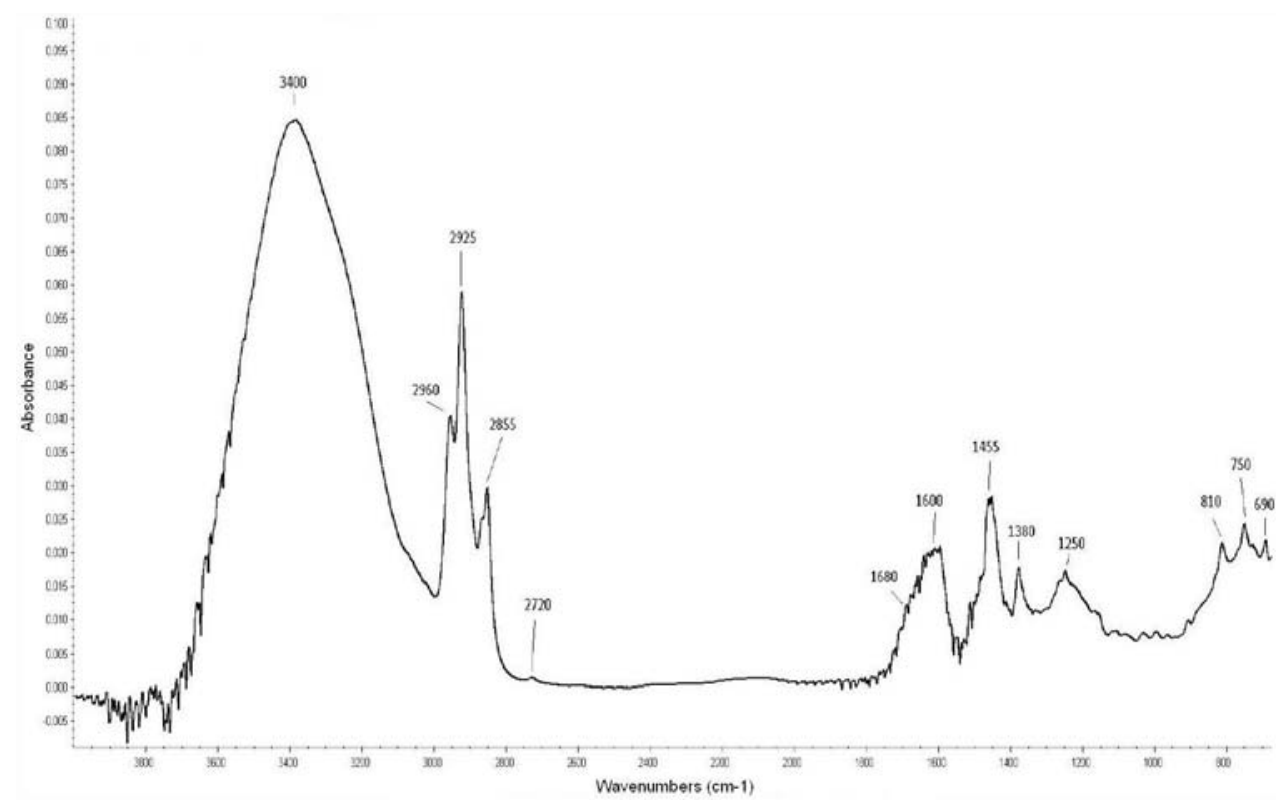

Fig. 3. IR spectrum of the pyrolytic oils - non-desulphurized coal (locality Jiří)

Rys. 3. Widmo IR olejów pirolitycznych - nieodsiarczonego węgla (miejscowość Jiří)

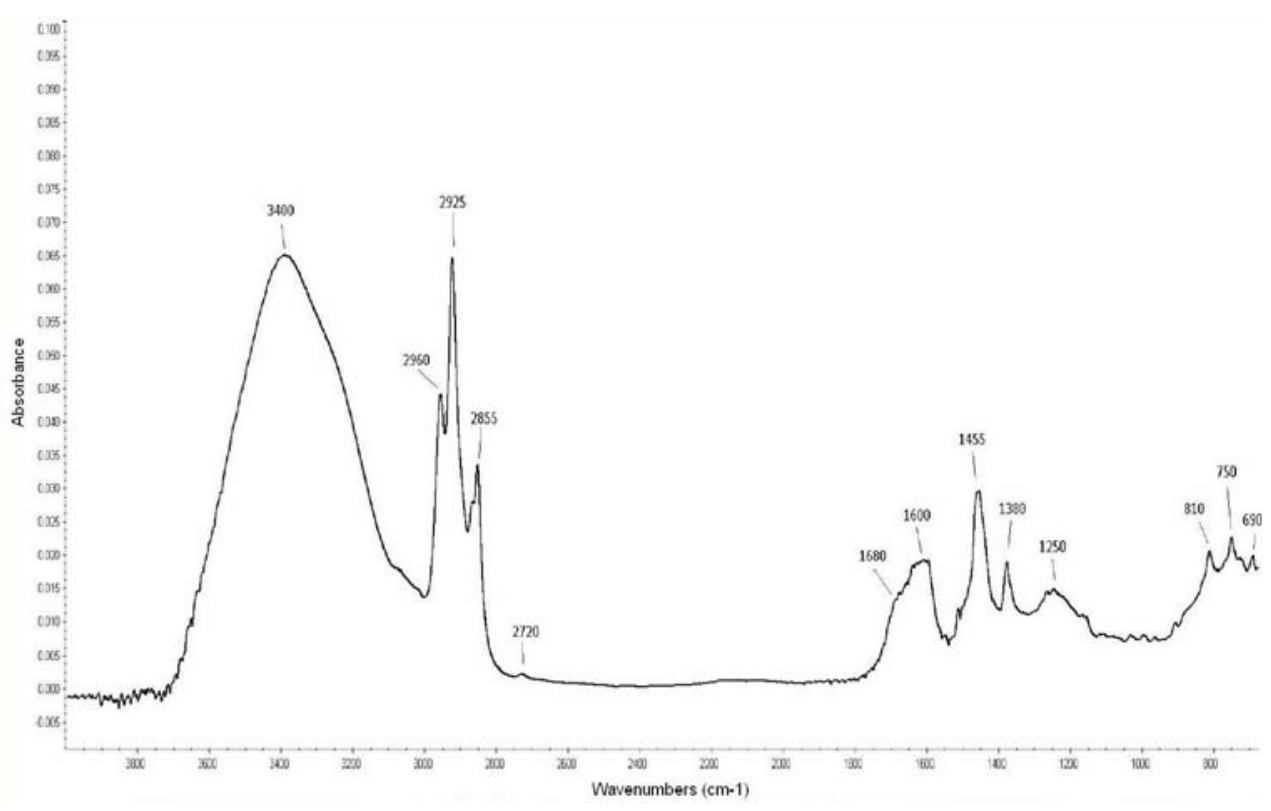

Fig. 4. IR spectrum of the pyrolytic oils - desulphurized coal (locality Jiří)

Rys. 4. Widmo IR olejów pirolitycznych - odsiarczony węgiel (miejscowość Jiří) 


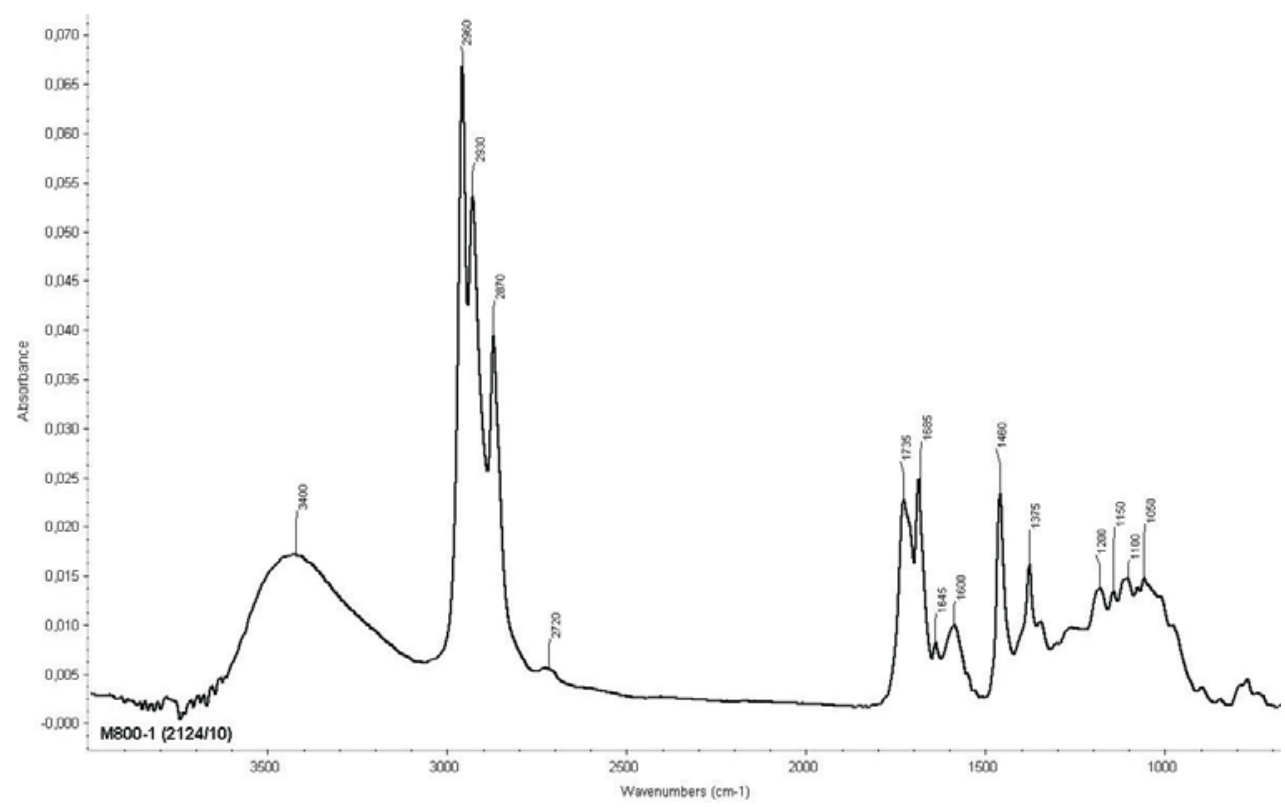

Fig. 5. IR spectrum of the flotation agent Montanol 800

Rys. 5. Widmo IR odczynnika flotacyjnego Montanol 800

- $1680 \mathrm{~cm}^{-1}\left(1685 \mathrm{~cm}^{-1}\right)$ valence vibrations of group $\mathrm{C}=\mathrm{O}$ in unsaturated or aromatic aldehydes and/or ketones,

- $1600 \mathrm{~cm}^{-1}$ valence vibrations of bond $\mathrm{C}=\mathrm{C}$ in aromatic hydrocarbons,

- $1460 \mathrm{~cm}^{-1}, 1380 \mathrm{~cm}^{-1}$ deformation vibrations of group $\mathrm{CH}_{3}$ and $\mathrm{CH}_{2}$ in aliphatic hydrocarbons,

$-1200 \mathrm{~cm}^{-1}\left(1250 \mathrm{~cm}^{-1}\right)$ deformation vibrations of group -OH in phenols.

As is clear from the figures, the spectra of the pyrolytic oils and of Montanol 800 predominantly differ in the extent of the individual peaks, but they are otherwise analogous. They contain identical bands. Even though it is not clearly specified, phenol contents may also be expected as determined in the Montanol 800 spectrum. Phenols were determined only in the spectra of Jiř́ sample pyrolytic oils, but the spectra of the Eliška 1 and 2 pyrolytic oil samples show a relatively prominent peak around $1250 \mathrm{~cm}^{-1}$, which belongs to the deformation vibration of the $\mathrm{OH}$ group in phenols. A number of different authors (Brossard, Cortez 1997; Brossard et al. 2008; Zámostný, Kur 2011) have confirmed the formation of phenols during pyrolysis. As flotation agents with a hydroxyl polar group are most frequently applied in coal flotation (Fečko 2001), pyrolytic oils may be classified there too.

First, pyrolytic oils were applied in flotation of black coal slurry from Lazy.

Figure 6 shows the concentrate yields and ash content values obtained by means of floating black coal slurry from Lazy. The top yield (almost 90\%) was obtained applying the 
62

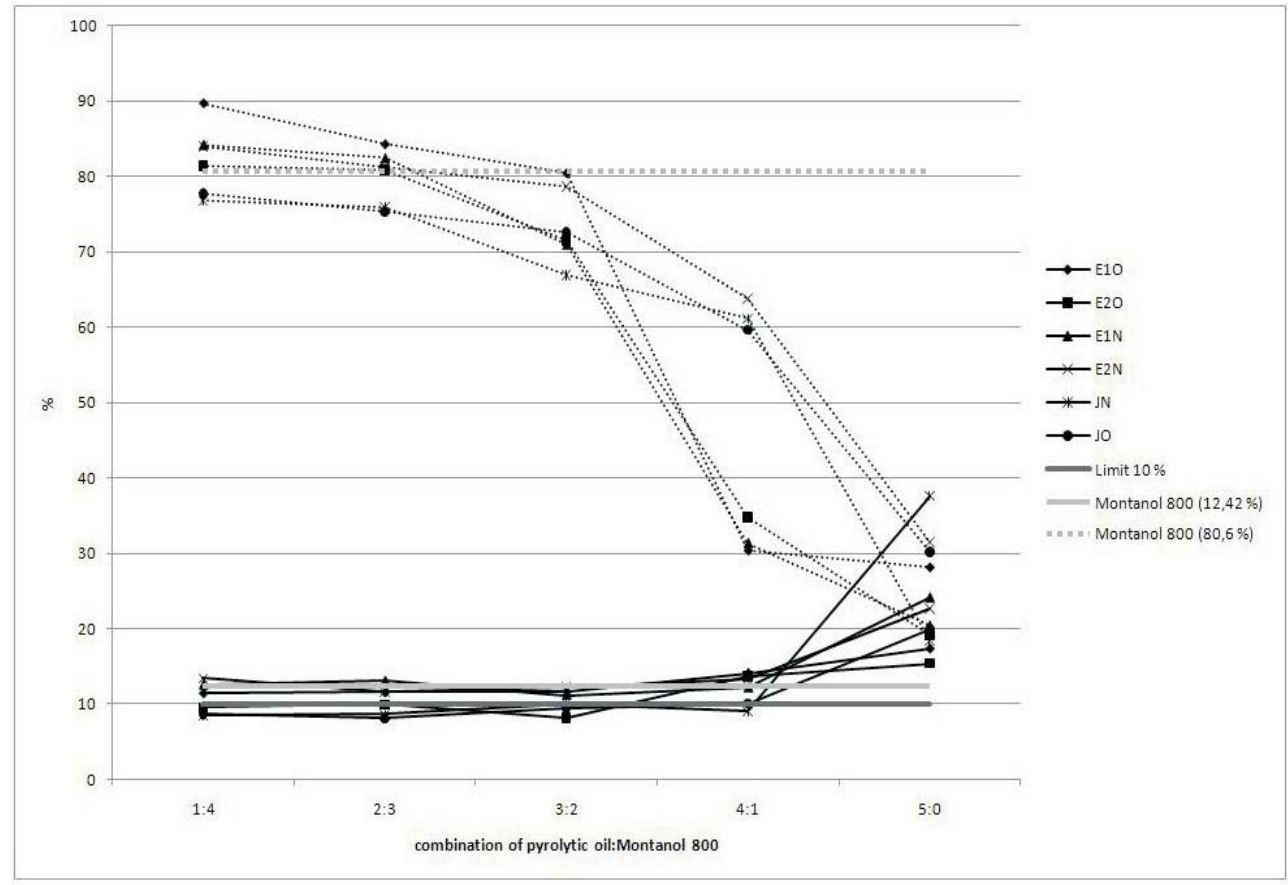

Fig. 6. Flotation results of black coal slurry from Lazy

E1(2)O(N) - Eliška 1(2) (non)desulphurized; JO(N) - Jiří (non)desulphurized; Limit 10\% - target ash content value; Montanol 800 - values obtained applying Montanol 800 only; dashed line - flotation concentrate yields; full line - ash content values

Rys. 6. Wyniki flotacji szlamów węgla kamiennego z Lazy

pyrolytic oil Eliška 1 - desulphurized combined 1:4 with Montanol 800. The ash content was $11.47 \%$. The lowest ash content value was produced applying both Jiří pyrolytic oils, i.e. 8.07 and $8.58 \%$, but the yields were around $76 \%$. As is apparent below, the higher the ratio of pyrolytic oil to Montanol 800 in proportions of 3:2 or greater, the lower the yields and the higher the ash in the concentrates. The ash content in tailings dropped as low as $30 \%$.

Figure 7 displays the concentrate yields and ash contents obtained in the flotation of black coal slurry from a Darkov settler. The conditioning lasted for 1 minute. The lowest ash content, i.e. $13.11 \%$, was achieved applying the pyrolytic oil Eliška 1 - non-desulphurized combined 2:3 with Montanol 800 where the concentrate yield was $78.26 \%$. The top yield of $81.64 \%$ was produced applying the pyrolytic oil Eliška 2 - non-desulphurized and Montanol 800 in a 1:4 proportion. As is clear from the figure, the required ash content was not achieved $(10 \%)$, thus the conditioning time was prolongued to 5 minutes. Next, there was a clear decrease in the concentrate yields and an increase in the ash content when the proportion of the pyrolytic oil in the mixture rose to $3: 2$ or greater. 


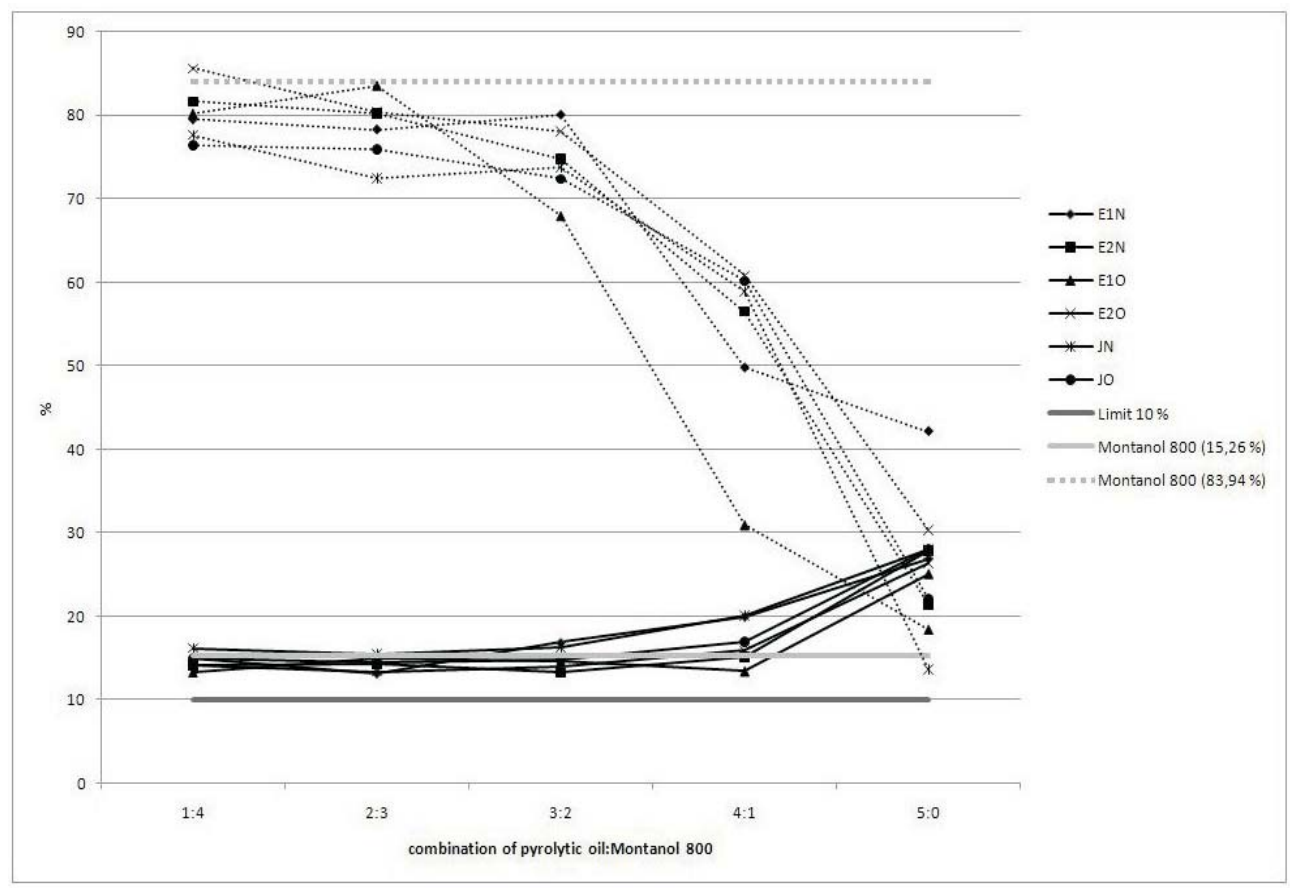

Fig. 7. Results of black coal slurry flotation from Darkov; 1-minute conditioning

E1(2)O(N) - Eliška 1(2) (non)desulphurized; JO(N) - Jiří (non)desulphurized; Limit 10\% - target ash content value; Montanol 800 - values obtained applying Montanol 800 only; dashed line - flotation concentrate yields; full line - ash content values

Rys. 7. Wyniki flotacji szlamów węgla z Darkov, 1 minuta mieszania

Figure 8 shows the values of ash content and the individual concentrate yields obtained by floating black coal slurry from a Darkov settler. The conditioning time was 5 minutes. The top yield was $83.85 \%$, which was obtained combining the pyrolytic oil Eliška 1 desulphurized and Montanol 800 in a proportion of 1:4. The ash content of the concentrate was $8.54 \%$. Overall, the ash content values dropped below $10 \%$ in all the applied pyrolytic oils, while the combination of the pyrolytic oils and Montanol 800 of 4:1 and 5:0 again led to a higher ash content and lower concentrate yields.

Comparing the flotation results when the pyrolytic oils of the Eliška and Jiř samples were applied, both from desulphurized and non-desulphurized brown coal, it cannot be unambiguously stated whether sulphur content in coal before pyrolysis influences the flotation process. Despite more satisfactory values of yields and ash contents in the case of desulphurized coal samples, the differences are minimal. The ash content varied in the order of tenths of percents and the variations in the yields measure in units of percents. This implies that desulphurization does not directly influence flotation, which is included mainly to reduce the sulphur compound contents arising during pyrolysis. 
64

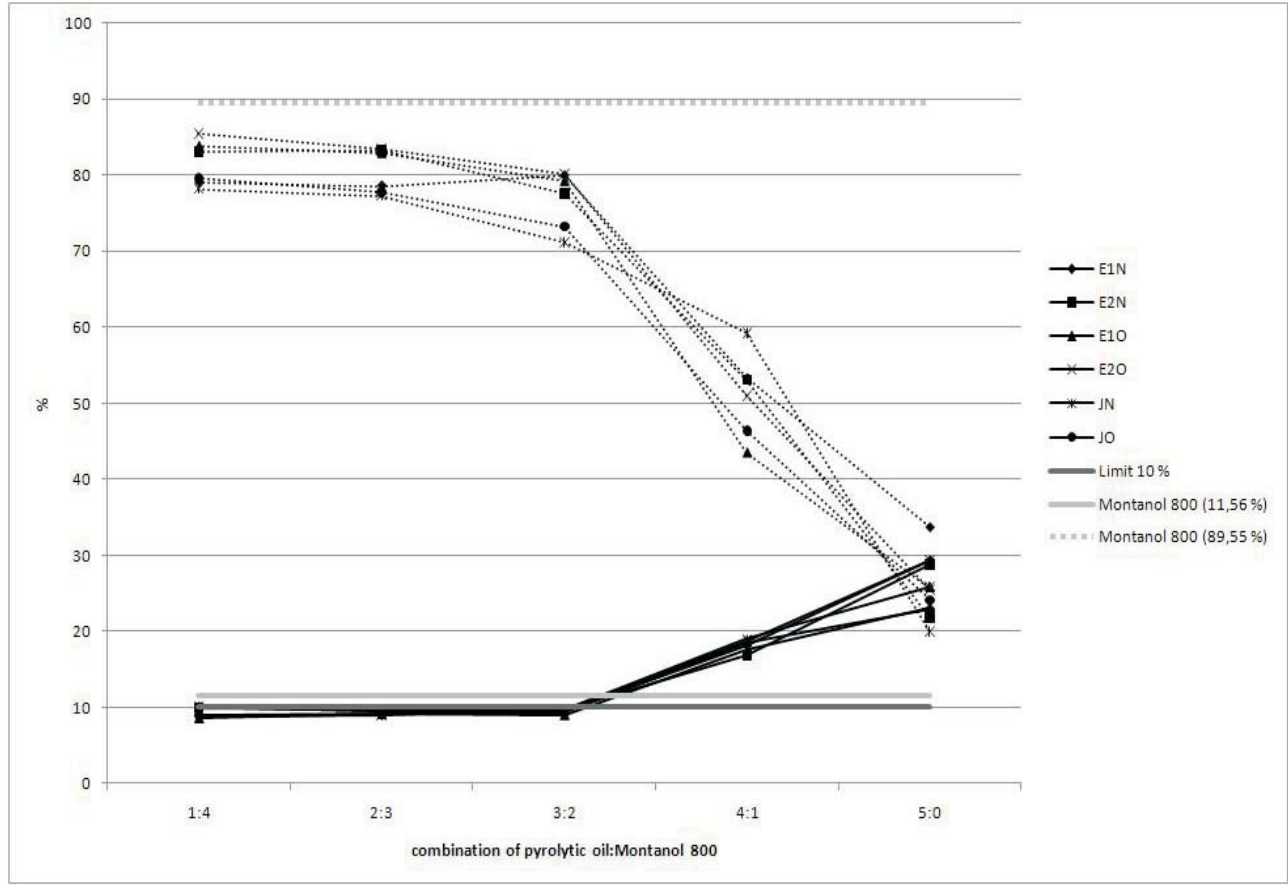

Fig. 8. Results of black coal slurry flotation from Darkov; 5-minute conditioning E1(2)O(N) - Eliška 1(2) (non)desulphurized; JO(N) - Jiř́i (non)desulphurized; Limit 10\% - target ash content value; Montanol 800 - values obtained applying Montanol 800 only; dashed line - flotation concentrate yields; full line - ash content values

Rys. 8. Wyniki flotacji szlamów węgla z Darkov, 5 minut mieszania

\section{Conclusion}

The objective of the experiment was to use pyrolytic oils from brown coal samples in black coal slurry flotation. Parts of the samples were subjected to pyrolysis directly and other parts of the samples underwent desulphurization by means of bacterial leaching before pyrolysis. The formed liquid pyrolytic products were subsequently tested as flotation agents to process black coal slurry, both separately as well as when mixed with the conventional flotation agent Montanol 800.

Bacterial leaching was included to verify whether sulphur content influences the flotation results. The FTIR analysis of the pyrolytic oils identified similarities to the conventional flotation agent Montanol 800.

The acquired flotation results imply that the application of pyrolytic oils in flotation may produce concentrates with lower ash content than the required $10 \%$, and also lower than that 
acquired using Montanol 800 . However, along with a rise in the proportion of the pyrolytic oil in a ratio of 3:2 or greater, there was a drop in the concentrate yields as well as an increase in their ash content. The ash content in the tailings also declined. As a result, it was confirmed that pyrolytic oils cannot be applied in the flotation process on their own, but rather that the required results are obtained only if they are mixed with the conventional flotation agent, i.e. Montanol 800. In addition, considering the sulphur content in the original brown coal samples, the impacts on the flotation results were not determined. The following conclusions may be drawn:

- in black coal slurry, flotation pyrolytic oils can be successfully applied only if mixed with a conventional flotation agent (Montanol 800); they are not effective on their own,

- sulphur content does not have a significant influence on the flotation results,

- the pyrolytic by-product, pyrolytic gas, shows properties making it suitable as an alternative fuel.

This article has been prepared in connection with the project Institute of clean technologies for mining and utilization of raw materials for energy use, reg. no. CZ.1.05/2.1.00/03.0082 supported by the Research and Development for Innovations Operational Programme financed by Structural Funds of the European Union and from the state budget of the Czech Republic.

\section{REFERENCES}

Aplan F.F., Arnold B.J., 1991 - Flotation. [In:] Leonard, J.W., Hardinge, B.C. Coal Preparation. SME, Littleton, CO. s. 450-485

B ros s ard L.E., Corte z L.A.B., 1997 - Potential for the use of pyrolytic tar from bagasse in industra. Biomass and Bioenergy., 12, 5, s. 363-366.

B ros s ard L.E., et al., 2008 - The role of phenols from bagasse vacuum pyrolysis bio-oil in cupper sulfured ore flotation. Brasilian Journal of Chemical Engineering, 25, 04, s. 723-728.

ČSN 38 5502, 1981 - Plynná paliva. Základní rozdělení. Praha: Úřad pro technickou normalizaci, metrologii a státní zkušebnictví.

ČSN 38 5509, 1990 - Plynná paliva. Fyzikální konstanty. Praha: Federální úřad pro normalizaci a měření.

ČSN 38 5521, 1960 - Stanovení spalného tepla a výhřevnosti topných plynů. Praha: Úřad pro technickou normalizaci, metrologii a státní zkušebnictví.

ČSN ISO 441313, 1997 - Hnědá uhlí a lignity: Zásady vzorkování. Praha: Český normalizační institut.

F e čk o P., 2001 - Netradiční způsoby úpravy černouhelných kalů. Ostrava, VŠB-TU Ostrava. 150 s.

F e čk o P., 2008 - Biotechnológie v úprave uhlia. Ostrava: Ediční středisko VŠB-TU Ostrava. $156 \mathrm{~s}$.

F e čk o P., et al., 2010 - Application of pyrolysis residue from waste materials on black coal flotation. Polish Journal of Chemical Technology, 2, s. 62-66.

G h a u r i M.A., et al., 2009 - Status of coal biotechnology in Pakistan. In DONATI, E.R., et al. 18th International Conference IBS. Bariloche, Argentina: [s.n.]. s. 513-516.

Hanson et. al., 2002 - Hanson S., Patrick J.W., Walker A., 2002 - The effect of coal particle size on pyrolysis and steam gasification. Fuel., roč. 85, 12-13, s. 531-537.

Kasztelewicz Z., 2004 - Rola węgla brunatnego w gospodarce. Gospodarka Surowcami Mineralnymi z. 3, s. $155-164$. 
Kristiansen A., 1996 - Understanding Coal Gasification. IEA Coal Research 86, London. 69 s.

Kříž V., 2005 - Dynamický model pyrolýzy uhlí s organickými odpady [s. 1]. 125 s. Dizertační práce. VŠB-TU Ostrava.

Kříž V., Brožová Z., 2007 - Co-pyrolysis of Coal/Waste Polymers Mixtures. Acta Geodynamica et Geomaterialia 2, s. 39-42.

Lorenz U., Grudziński Z., 2005 - Sytuacja na międzynarodowych rynkach węgla energetycznego. Gospodarka Surowcami Mineralnymi z. 2, s. 6-16.

Zámostný P., Ku rc L., 2011 - Vliv podmínek a složení suroviny na pyrolýzu dřevní hmoty. Chemické Listy. 105,6 , s. 458-466.

ZASTOSOWANIE OLEJÓW Z PIROLIZY WĘGLA BRUNATNEGO DO FLOTACJI SZLAMÓW WĘGLA KAMIENNEGO

\author{
Słowa kluczowe
}

Węgiel brunatny, piroliza, bakteryjne odsiarczanie, Acidithiobacillus ferrooxidans

\title{
Streszczenie
}

Praca dotyczy możliwości wykorzystania olejów z pirolizy węgla brunatnego i zastosowania ich w sposób opisany poniżej. Po pierwsze, próbki węgla brunatnego zostały pobrane z największego Regionu (Československá Armada Mine) i Regionu Sokolov (MineJiří) i odpowiednio przygotowane w celu uzyskania wymaganej wielkości ziarna. Próbki węgla były poddane pirolizie w zamkniętym reaktorze rurowym w temperaturze $900^{\circ} \mathrm{C}\left(5^{\circ} \mathrm{C} / \mathrm{min}\right.$, przez okres 30 minut), a uzyskanym produktem była ciecz. Skład tych olejów pirolitycznych (alifatyczne i aromatyczne węglowodory, alkohole i grupy funkcyjne) jest analogiczny jak w przypadku odczynników konwencjonalnych do flotacji węgla (w tym przypadku Montanol 800). Oleje użyto w procesie flotacji szlamów węgla kamiennego z Regionu Karwiny (z kopalni Lazy i osadnika z kopalni Darkov). Oleje pirolityczne stosowano w mieszaninie z Montanolem $800 \mathrm{w}$ dawce $500 \mathrm{~g} / \mathrm{Mg}$ i proporcje poszczególnych odczynników różniły od 1:4 do 5:0 (pirolityczny olej: Montanol 800). Ostateczne wartości, czyli uzysk koncentratu i zawartość popiołu, zostały porównane z wartościami uzyskanymi przy zastosowaniu czystego Montanolu 800. Zawartość popiołu w koncentracie flotacyjnym została ustalona na poziomie $10 \%$. Węgiel zawiera siarkę, której związki są przeniesione do płynnych produktów podczas pirolizy. Niektóre próbki węgla brunatnego poddano bakteryjnemu odsiarczaniu węgla stosując czyste kultury bakterii Ferrooxidans Acidithiobacillus w celu ustalenia, czy zawartość siarki ma wpływ na wyniki flotacji. Wyniki potwierdziły, że oleje pirolityczne mogą być stosowane do flotacji szlamów węgla, a otrzymane koncentraty będą zawierać poniżej $10 \%$ popiołu. Jednak może to być osiagnięte jedynie poprzez zmieszanie olejów z Montanolem 800; stosowanie samego oleju pirolitycznego nie dało zadowalających wyników. Pośrednim wynikiem eksperymentu było określenie ciepła spalania i wartości gazu pirolitycznego. Wyniki sugerują, że może on być stosowany jako paliwo alternatywne.

\section{APPLICATION OF BROWN COAL PYROLYTIC OILS IN BLACK COAL SLURRY FLOTATION}

$$
\text { Key words }
$$

Brown coal, pyrolysis, bacterial desulphurization, Acidithiobacillus ferrooxidans

\section{Abstract}

This paper deals with the possible use of brown coal pyrolytic oils prepared and applied as described below. First, brown coal samples were drawn from the Most Region (Československá armáda Mine) and Sokolov Region 
(Jiří Mine) and processed to obtain a required grain size. The samples were pyrolyzed in a closed tube reactor at $900^{\circ} \mathrm{C}\left(5^{\circ} \mathrm{C} / \mathrm{min}\right.$, holding time of 30 minutes $)$, and the resulting liquid product was collected. As the composition of the pyrolytic oils (content of aliphatic and aromatic hydrocarbons, alcohol, and functional groups) is analogous to that of a conventional flotation agent (in this case Montanol 800), the oils were used in a flotation process to float black coal slurry from the Karviná Region (from Lazy Mine and a settler of Darkov Mine). The pyrolytic oils were applied in a mix with Montanol 800 in a dose of $500 \mathrm{~g} / \mathrm{t}$, and the individual proportions of the agents differed from 1:4 to 5:0 (pyrolytic oil:Montanol 800). The final values, i.e. concentrate yields and ash contents, were compared with the reference values obtained when applying pure Montanol 800. The limit of ash content in the flotation concentrate was set at $10 \%$. As coal contains sulphur, the compounds of which transfer into the liquid products during pyrolysis, some brown coal samples underwent bacterial desulphurization using a pure bacterial culture of Acidithiobacillus ferrooxidans, in order to find out whether sulphur content influences the flotation results in any way. The results confirmed that pyrolytic oils may be applied in the black coal slurry flotation process, and concentrates with ash content below $10 \%$ may be obtained. However, this can only be achieved through mixing the oils with Montanol 800 as the application of the pyrolytic oil alone did not provide satisfactory results. An indirect output of the experiment was the determination of the net and gross heat of combustion for the pyrolytic gas. The results imply that it may be used as an alternative fuel. 
